\title{
RESPONSIBILITY OF A JUVENILE FOR A Prohibited Act under Polish LaW
}

\author{
Paweł Daniluk \& Joanna Mierzwińska-Lorencka \\ Institute of Law Studies, Polish Academy of Sciences
}

paw87@wp.pl,mierzwinka@wp.pl

DANILUK Paweł \& MIERZWIŃSKA-LORENCKA, Joanna. Responsibility of a Juvenile for a Prohibited Act under Polish Law. International and Comparative Law Review, 2016, vol. 16, no. 2, pp. 99-115. DOI: 10.1515/iclr-2016-0017.

\begin{abstract}
Summary: The law on juvenile delinquency proceedings creates a model of a paternalistic and welfare approach to juvenile justice, the protection and treatment of the juvenile at risk oriented allowing only a certain range, to use criminal sanctions against juvenile perpetrators of prohibited acts. The rule is that juvenile is not liable to the principles defined in the Penal Code, the Code of Petty Offences or the Fiscal Penal Code, and the law is applied to him is the Juvenile Act of 26 October 1982 which does not provide for a criminal responsibility. Special, nonpenal responsibility for juveniles applies for those between 13 and 17 years. For younger juveniles, special measures of exclusively educational and care character are possible.
\end{abstract}

Keywords: special juvenile responsibility, concept of juvenile, juvenile measures, age of criminal responsibility

\section{Age of Criminal Responsibility and The Notion of a Juvenile in Polish Criminal Law}

On the basis of the broadly understood Polish criminal law, whose basic legal acts are the Act of 6 June 1997 - Criminal Code (hereinafter referred to as the P.C. $)^{1}$, the Act of 20 May 1971 - Code of Petty Offences (hereinafter referred to as the C.P.O.) ${ }^{2}$ and the Act of 10 September 1999 - Fiscal Penal Code (hereinafter referred to as the F.P.C.) $)^{3}$, the concept of a juvenile understands the perpetrator of a prohibited act as an offence, fiscal offence, petty offence or fiscal petty offence,

1 The Penal Code is the basic legal act of the Polish criminal law in the sensu stricto sense, which regulates criminal responsibility of offences.

2 The Code of Petty Offences is the basic legal act of the Polish petty offences law, which is a part of the Polish penal law in the broad sense. The petty offences law regulates criminal liability in the sensu largo sense for petty offences, which are finer or less socially dangerous criminal acts than offences.

3 Fiscal Penal Code is the basic legal act of the Polish fiscal law, which is a part of the Polish criminal law in the broad sense. Fiscal Penal Law regulates criminal liability for fiscal offences and fiscal petty offences, and the separation is due to the specialized subject of fiscal offences protection norms. Namely, these norms protect the financial interests of the treasury and local government units. 
which because of the age is considered to lack the capacity to criminally responsible and thus could not be criminally responsible. This means that juvenile, as a rule, is not liable to the principles defined in the P.C., the C.P.O. or the F.P.C., and the law is applied to him is the Juvenile Act of 26 October 1982 (hereinafter referred to as the J.A.) which does not provide for a criminal responsibility ${ }^{4}$.

Polish criminal law traditionally because since the first modern Polish criminal codify what was the regulation of the President dated 11 July 1932 - Criminal Code, involves the ability to bear criminal responsibility of the age of 17 years. P.C. in the article $10 \$ 1$, C.P.O. in the article 8 and F.P.C. in the article $5 \$ 1$ explicitly state that under the terms of the codes respond to the one who had committed a prohibited act after having reached 17 years of age. In this way it sets the minimum age from which updates the ability to bear criminal liability for committing an offence, fiscal offence, petty offence and fiscal petty offence. In accordance with those provisions, the responsibility may suffer only a person who commits a prohibited act after having attained 17 years of age. The perpetrator who committed a prohibited act before reaching the specified age is not criminally responsible.

Although the P.C., the C.P.O. and the F.P.C. do not define expressions "adult" and "juvenile" and do not use them in the articles $10 \$ 1$ P.C., 8 C.P.O. or $5 \$ 1$ F.P.C., it is accepted that a person who commits a prohibited act after having attained 17 years of age, is an adult, and the one who commits a prohibited act before having attained the age of 18 years is a juvenile. Calling juvenile perpetrators, which at the time of its commission has not completed 17 years does not correspond fully with the notion of a juvenile in the J.A. This Act provides for three - differently understood - categories of juveniles and none of them is semantically identical the above mentioned terms of the P.C., the C.P.O. and the F.P.C.

Article $10 \$ 1$ P.C., article 8 C.P.O. and article $5 \$ 1$ F.P.C. - acting on the commission of a prohibited act after the completion of 17 years - refers to the time of the prohibited act specified in the article $6 \$ 1$ P.C., art. $4 \$ 1$ C.P.O. and article 2 $\$ 1$ F.P.C. Under these provisions, a prohibited act is deemed to have been committed at the moment when the perpetrator has acted or has omitted an action he has been obliged to perform (was the behavior of the perpetrator). Criminal liability should be imposed only on perpetrators who had completed 17 years at the time of action or lack of action (to what was required), realizing the mark of the type of a prohibited act defining the behavior of the perpetrator. To determine whether the offender has committed a prohibited act after completing 17 years have no meaning other than the time of action or omission moments of time. In particular, time of occurrence is negligible effect, which is the mark of a prohibited act. In addition, there is no doubt irrelevance time of a trial court

4 A. Wąsek rightly said that the J.A. is not a legal act belonging to the criminal law (WĄSEK, Andrzej. Penal Code. Commentary. Gdańsk: Arche, 1999, pp. 130-131. 
sentencing. Therefore, if the offender committed a prohibited act before the age of 17 years and at the time of a trial court sentencing has already completed 17 years is not subject to criminal liability under the rules provided in penal law.

\section{Ability to fault}

The regulations of articles $10 \$ 1$ P.C., 8 P.C.O. and $5 \$ 1$ F.P.C. are based on the assumption that a person from the moment of completion of 17 years reaches a level of intellectual, social and moral development that allows to recognize correctly the importance of committed acts and their conduct ${ }^{5}$. Proper recognition of the importance of committed acts refers both to the ontology layer including bio-physical and causal consequences of the act (e.g. a person who completed 17 years should be aware that the task to another person a blow with a knife can cause death or injury), as well as their axiological layer on the moral and legal assessment of the act (e.g. a person who reached 17 years should be aware that you can not take other people's things). The opportunity to guide their behavior refers to being able to control their behavior and adapt it to the ontological and axiological recognition of its importance.

Achieving the level of intellectual, social and moral development, which allows correct recognizing the importance of committed acts and their conduct is a necessary condition for the assignment guilty ${ }^{6}$. Perpetrators of being incapable of either recognizing the significance of his act or controlling his conduct can not be charged with a prohibited act which is the essence of guilt under criminal law. At the basis of this accusation is that the offender has committed a prohibited act under conditions (situation) in which you can require a different, lawful behavior.

Thereby, achievement by the age specified in articles $10 \$ 1$ P.C., 8 C.P.O. and $5 \$ 1$ F.P.C. of the perpetrator is the premise of the assignment guilty. However, the perpetrator of a prohibited act who not reached the age is incapable of guilt and unable to bear criminal responsibility. The doctrine notes additionally, as it were presented issues of guilt, that the necessity of differential treatment of juveniles and the abandonment of pulling them to criminal liability is justified inexpediency, or even harm punish them according to the rules prescribed for adult perpetrators of criminal acts. In particular, it is pointed out that the punishment of juveniles by these rules precipitate them from the normal, appropri-

5 GIEZEK, Jacek (ed.). Criminal Code. General Section. Commentary. Warsaw: Wolters Kluwer, 2007, p. 87; GRZEŚKOWIAK Alicja, WIAK, Krzysztof (eds.). Criminal Code. Commentary. Warsaw: C.H. Beck, 2012, p. 102.

6 In the Polish criminal law only a person who commits an act that is culpable shall be subject to criminal liability. That is clear from art. $1 \S 3$ P.C., art. $1 \S 2$ C.P.O. and art. $1 \S 3$ F.P.C. The guilty under Polish criminal law will have to deal when the accusation can be made because of committed act. At the core of this accusation is the fact that the offender has committed a prohibited act under conditions (situation) in which you can from it require a different, lawful behavior. 
ate for children and young people in a certain age, the rhythm of functioning, stigmatize as criminals and socially marginalized them ${ }^{7}$.

\section{Degree of the particular perpetrators development}

\subsection{Preliminary remarks}

Adoption on the basis of article $10 \$ 1$ P.C., 8 C.P.O. and $5 \$ 1$ F.P.C. that the person at the completion of 17 years reaches a degree of intellectual, social and moral development, that allows it to correctly recognize the importance of committed acts and their conduct is a certain assumption or presumption. These provisions do not take into account while the actual degree of development of individual perpetrators. It is clear also for the rational legislator that in fact the dynamics of development is not the same for each person. These makes the perpetrators who despite not having concluded at the time of a prohibited act 17 years correctly recognize its importance and are fully able to control their conduct. On the other hand there are also perpetrators who despite the completion at the time of a prohibited act 17 years not actually recognize its significance or are not fully able to direct his actions.

On the basis of Polish criminal law these circumstances are taken into account by the legislator but only to a limited extent in a disaggregated way different in particular Codes.

\subsection{Penal Code}

The greatest flexibility when it comes to taking into account the actual degree of particular perpetrators development characterized by the P.C. In this regard, it should be pointed to the article $10 \$ 2$ P.C., which introduces an exception to the rule in the article $10 \$ 1$ P.C. and allows criminal prosecution (under the P.C.) a juvenile who after the age of 15 committed one of the prohibited act, exhaustively listed in the article $10 \$ 2$ P.C. These are the following prohibited acts: the assassination of the President of the Polish Republic, the murder of a person in the basic type and the types of eligible, causing serious damage to human health, in this resulting in his death, to bring an event that threatens the life or health of many persons or property in large sizes, including resulting in death of man or severe damage to the health of many people, take control of the ship or aircraft using deceit or violence to a person or threat of immediate use of such violence, including causing immediate danger to life or health of many persons or human death or serious bodily injury of many people, bringing the disaster in motion by land, water or air, threatening the life or health of many persons or property in large sizes, this resulting in the death of a man or severe damage to the health of many people, rape, together with another person, to a minor under 15 years

7 KONARSKA - WRZOSEK, Violetta. Legal System of Dealing with Minors in Poland. Warsaw: Wolters Kluwer, 2013, pp. 29-30. 
of age or to ascendant, descendant, adoptee, adopter, brother or sister, including with particular cruelty, admission an assault on a public official or person to help him foster during or in connection with the performance of official duties, acting jointly and in concert with another person or using a firearm, knife or other similarly dangerous object or means overwhelming, if as a result of the assaults occurred due in the form of serious injury to a public official or person to help him foster, taking or keeping hostage to force the state authority or local government, institutions, organizations, natural or legal person or group of persons to a particular behavior, including binding with special torment hostage, robbery with use of violence against a person or threat of immediate its use or of bringing man to a state of unconsciousness or helplessness, including the use of a firearm, a knife or another similarly dangerous object or incapacitating agent, or acts in another immediately life-threatening manner or jointly with another person handling such weapon, object or agent, or acting in such manner.

It seems that the intention of the legislator in the catalog of prohibited acts of article $10 \$ 2$ P.C. were to be the most serious offences ${ }^{8}$. If so, recognition of this directory can inspire and raises reasonable doubt, related primarily to the omission in it at least several serious offences, such as e.g. taking activity aimed directly to eliminate violence the constitutional authority of the Polish Republic, trafficking in human beings, the use of violence against a person or threat of immediate to use it, or bring people to a state of unconsciousness or helplessness, immediately after the theft, in order to maintain the possession taken away things?.

The condition of criminal liability of the juvenile who after the age of 15 committed one of the above prohibited acts is to appeal for the circumstances of the case and the degree of the perpetrator's development, his characteristics and personal conditions, especially if educational or correctional measures that had been applied previously have proven to be ineffective. Criteria referred in the article $10 \$ 2$ P.C. are not defined in the P.C. What's more, they appear to be vague and difficult to unambiguous interpretation. This state of affairs is not met, however, with a uniform evaluation. On the one hand it is subject to criticism, in which it is alleged that the conditions of the article $10 \$ 2$ P.C. as vague leave excessive discretion the courts which is not enough to guarantee in relation to a juvenile ${ }^{10}$. On the other hand rises that vague indications of the article $10 \$$ 2 P.C. to ensure the application of this provision in a way that maximally individualized and flexible which is needed for proper settlement of specific cases ${ }^{11}$. Despite these differences in the assessment of how to approach article $10 \$ 2$ P.C. according to the doctrine it is assumed that this provision as sets forth an

8 KONARSKA - WRZOSEK, Violetta. op. cit., p. 122.

9 HAŁAS, Radosław. Criminal responsibility of juveniles under the Penal Code of 1997. Lublin: KUL, 2006, pp. 85-87.

10 GRZEŚKOWIAK Alicja, WIAK, Krzysztof (eds.). op. cit., p. 105.

11 WĄSEK, Andrzej. op. cit., p. 134. 
exception to the general rule of criminal irresponsibility of juveniles can not be interpreted broadly ${ }^{12}$. A restrictive interpretation of the article $10 \$ 2$ P.C. seems to accompany practice. V. Konarska-Wrzosek reports, citing data of the Ministry of Justice, that pulling the juvenile to criminal responsibility under article 10 $\$ 2$ P.C. occurs rarely. The number of juveniles convicted under this provision amounted in $2005-24,2006-19,2007-25,2008-10,2009-25,2010-14^{13}$.

The most striking premise, which is to speak at the pull of a juvenile to criminal liability under article $10 \$ 2$ P.C. is "the degree of the perpetrator's development". It emphasizes that criminal liability of the juvenile is the responsibility based on the principle of guilt and can not be deem as a liability of the person unable to fault (exception to the principle of guilt expressed in article $1 \$ 3$ P.C.). This was indeed the legislator's intention, as evidenced by the justification of the project of the P.C. which stated in relation to article $10 \$ 2$ P.C. that "in the context of the circumstances of the person causing the" accentuates the "degree of development" which is "a clear reference to the possibility of bringing the perpetrators plea from his actions, and so establish his guilt" ${ }^{\text {"1 }}$. Basing criminal responsibility of juvenile on the principle of guilt as referred to in article $10 \$ 2$ P.C. is also confirmed in the formulation of this provision that juveniles may correspond to "the principles laid down in the Code". After all, one of the principles set out in the P.C. is the principle of guilt $(1 \S 3 \text { P.C. })^{15}$.

Perceiving the " the degree of the perpetrator's development ", as referred to in article $10 \$ 2$ P.C., through the prism of the principle of guilt, it is clear that he will be speaking at the pull of a juvenile to criminal liability when a young perpetrator who at the time of the prohibited act was on the degree of intellectual, social and moral development, which enabled him to properly recognize the importance of having committed action and their conduct, which is a prerequisite for apportioning blame.

"Properties and personal conditions" is a phrase that is quite often used in the P.C. provides the basis for assessing a perpetrator and the situation of perpetrator. It looks similar under article $10 \$ 2$ P.C. where personal properties include age, health, personality and character, the degree of demoralization of the juvenile, and personal circumstances to the social environment of the juvenile, and especially the family environment, environment, colleagues or other environment where the juveniles resides ${ }^{16}$.

12 GRZEŚKOWIAK Alicja, WIAK, Krzysztof (eds.). op. cit., p. 105; WĄSEK, Andrzej. op. cit., p. 137.

13 KONARSKA - WRZOSEK, Violetta. op. cit., p. 135.

14 The new criminal codes with justifications (Warsaw, 1997) p. 123.

15 GABERLE, Andrzej, Criminal responsibility of juveniles (remarks on the background of article $10 \$ 2$ P.C.), In GIEZEK, Jacek (ed.). Crime - punishment - criminal policy. Problems of creation and functioning of the law. The jubilee book on the occasion of Professor Tomasz Kaczmarek seventieth birthday. Cracow: Zakamycze, 2006, p. 178.

16 KONARSKA - WRZOSEK, Violetta. op. cit. p. 124; WĄSEK, Andrzej. op. cit., p. 135. 
The most capacious and broadly defined premise of article $10 \$ 2$ P.C. are the "circumstances of the case." It seems that this premise should be viewed as complementary in relation to the other conditions of article $10 \$ 2$ P.C. ${ }^{17}$ while closely associated with a particular incident, which is committing a prohibited act referred to in that provision. Thus, the circumstances of the case must be understood as subjective and objective characteristics of the crime, including the behavior of the perpetrator (e.g. the brutality, aggressiveness), its motivation, and caused damage (material or immaterial) ${ }^{18}$.

Special premise strokes juvenile to criminal responsibility is the ineffectiveness of previous measures applied educational or corrective according to the provisions of the J.A. The specific nature of this condition lies in the fact that - unlike other conditions of article $10 \$ 2$ P.C. they need not be met to initiate the criminal responsibility of a juvenile. Convinces the preceding of this premise with the phrase "in particular" which clearly indicates that this circumstance is purely exemplary. Consequently there is the possibility of holding a juvenile to criminal responsibility in accordance with article $10 \$ 2$ P.C. when for example, in general, has not been used previously to him of educational or correctional measures. However, if such measures had been applied previously and have proven to be ineffective then this could be a very important argument for the stroke of a juvenile to criminal liability.

Pulling the juvenile to criminal responsibility in accordance with article 10 $\$ 2$ P.C. is optional. It is possible that in the situation that all the conditions of article $10 \$ 2$ P.C. the court refrains from strokes juvenile to criminal responsibility and stop with the use of the measures provided for in the J.A. The court in deciding whether to start criminal responsibility of a juvenile pursuant to article $10 \$ 2$ P.C. should be guided by the best interests of the juvenile which is a basic principle of the law on juvenile justice (article $3 \$ 1$ J.A.) ${ }^{19}$.

Pulling the juvenile to criminal responsibility in accordance with article 10 $\$ 2$ P.C. does not mean that he is treated on the same basis as an adult perpetrator. We are dealing here with some of difference in terms of punishment. First of all, pay attention to the special directive sentencing a juvenile. It has been recognized in the article $54 \$ 1$ P.C. and it states that while imposing a penalty on a juvenile, the court aims primarily at educating the perpetrator. The penalty predicated for juvenile is therefore serving primarily an educational function in the detail preventive sense. This does not mean, however, warrant a mild punishment of juveniles, because in some cases educational function can meet only punishment severe ${ }^{20}$.

17 WĄSEK, Andrzej. op. cit., p. 134.

18 KONARSKA - WRZOSEK, Violetta. op. cit., pp. 122-123.

19 HAŁAS, Radosław. op. cit., p. 91; MARASZEK, Magdalena. Minimum age of criminal responsibility in Polish law. Warsaw: Wolters Kluwer, 2012, p. 129.

20 KONARSKA - WRZOSEK, Violetta. op. cit., p. 132. 
Another difference in the range of punishment of juveniles were expressed in article $54 \$ 2$ and $10 \$ 3$ P.C. The first of those provisions strictly prohibits the rule for the penalty of deprivation of liberty for life against the perpetrators who has not attained 18 years of age while committing an offence. This is justified as indicated by the legislator himself in the grounds of the draft of P.C. including the process of socialization of the perpetrators at that age is not yet generally completed ${ }^{21}$. On the other hand, article $10 \$ 3$ P.C. states that the imposed penalty may not exceed two-thirds of the upper limit of the statutory penalty prescribed for a crime attributed to the perpetrator. At the basis of this regulation the belief of the legislator is that: "The guilty in the case of criminal liability of juveniles is always limited by the lack of maturity of the perpetrator. The introduction of reduced border threats gives expression to the principle of accepting the penalty can not exceed its severity degree of guilt"22. In addition, article $10 \$$ 3 P.C. is a spontaneous basis optional extraordinary mitigation of penalty (generally speaking extraordinary mitigation of the penalty involves a sentence below the statutory limit risk or a milder type of penalty by the rules - see especially article $60 \$ 6$ P.C.).

According to the provisions of P.C. the actual degree of development of individual perpetrators is taken into account also under the article $10 \$ 4$ P.C. This provision requires the court order in relation to a perpetrator who has committed a misdemeanor ${ }^{23}$ after having attained 17 years of age, but before attaining 18 years of age instead of a penalty impose educational, therapeutic or correctional measures prescribed for juveniles in the J.A. if it is expedient due to the circumstances of the case and the degree of perpetrator's development, his characteristics and personal conditions. On the basis of this regulation the court has an obligation, not a possibility as in the case of article $10 \$ 2$ P.C., to treat the adult perpetrator, so the one who has committed a prohibited act after completing 17 years as a juvenile which involves applying to him instead of a penalty educational, medical or correctional measures prescribed for juveniles in the J.A. This obligation is updating when an adult offender committed an offence before the age of 18 years, and for the use of educational, medical or correctional measures speak circumstances of the case and the degree of development of the perpetrator, his personal characteristics and conditions.

Conditions described in article $10 \$ 4$ P.C. by the words "circumstances of the case", "degree of development of the perpetrators", "personal characteristics and

21 The new criminal codes with justifications. Warsaw 1997, p. 142.

22 The new criminal codes with justifications. Warsaw 1997, p. 123.

23 According to the art. $7 \$ 1$ P.C., crimes under the Polish criminal law are divided into felonies and misdemeanours. A felony is a prohibited act penalized with the penalty of deprivation of liberty for a period of no less than 3 years or with a more severe penalty (art. $7 \S 2$ P.C.). A misdemeanor is a prohibited act penalized with a fine exceeding 30 daily rates or exceeding PLN 5,000, the penalty of limitation of liberty exceeding one month or the penalty of deprivation of liberty exceeding one month (art. $7 \$ 3$ P.C.). 
conditions" are the same as in article $10 \$ 2$ P.C. and they have the same meaning in both of those provisions. The essence of the regulation of article $10 \$ 4$ P.C. is similarly as in art. $10 \$ 2$ P.C. with reference to the degree of development of the offender, which is a direct reference to the issue of guilt. On the basis of article 10 $\$ 4$ P. C. degree of development of the perpetrators will speak for using instead a penalty of educational, medical or correctional measures when an adult offender at the time of the prohibited act was characterized by the degree of intellectual, social and moral development, which stood in the way of fully proper recognition of the importance of the committed act and directing his actions.

\subsection{Code of Petty Offences}

In contrast to the P.C. a total lack of flexibility when it comes to taking into account the actual degree of development of particular perpetrators, characterized by the C.P.O. This is due to the fact that the minimum age of criminal responsibility determined the art. 8 C.P.O. is a rigid (without exception). In particular, the C.P.O., contrary to article $10 \$ 2$ P.C. does not provide a unique possibility of criminal liability offender who committed a prohibited act before the age of 17 years. Thus the actual achievement by the perpetrator of such a level of development that enabled him to properly recognize the importance of the committed act and their conduct, does not allow for pulling him criminally responsible for a petty offence if he has not completed 17 years at the time of the act.

The total lack of flexibility in the C.P.O. when it comes to taking into account the actual degree of development of particular perpetrators however is not the subject of criticism. On the contrary such a solution is assessed in the literature as a fully accurate "petty offences as acts of a finer nature must be evaluated (...) a bit different than criminal offences. Establishing a permanent border 17 years is quite sufficient for the application responsible for the petty offence without reduction" ${ }^{\prime 2}$.

\subsection{Fiscal Penal Code}

We have slightly different situation while dealing on the basis of the F.P.C. There is already article $5 \$ 1$ F.P.C., which requires completion of 17 years of reserves at the same time "unless the provision of the act provides otherwise" for criminal responsibility. Despite such reservations the F.P.C. does not provide for lowering the age of criminal responsibility. However, it contains the regulation which obliges the court to apply to the perpetrator who committed a fiscal offence or fiscal petty offence after having attained 17 years of age, but before having attained the age of 18 years, instead of a penalty or penal measure, educational, therapeutic or correctional measure provided for juveniles in the J.A. The condition of such a ruling is appealed to the circumstances of the case, the degree

24 BOJARSKI, Tadeusz. Polish petty offences law. Outline of lecture. Warsaw: LexisNexis, 2012, p. 67. 
of development of the offender and his personal characteristics and conditions (5 $\$ 2$ F.P.C.). This is analogous to the adjustment provided for in article $10 \$ 4$ P.C., ordering to treat as a juvenile the adult offender who has committed a prohibited act after completing 17 years. In this context we are therefore faced with a regulation flexibiliser principle of article $5 \$ 1$ F.P.C. and taking into account the actual degree of development of particular perpetrators.

The fact that the current legal F.P.C. does not provide for lowering the age of criminal responsibility meets with approval. Elevated by the fact that due to the nature of fiscal offences and fiscal petty offences that belong more to the category of mala prohibita than mala per se a breach of the principle of fiscal criminal irresponsibility of juveniles would have no rational justification ${ }^{25}$.

Legislator has prepared the F.P.C. for emergency lowering the age of criminal responsibility and take the responsibility of juveniles. He did this by posting in the F.P.C. a difference in terms of penalty of juveniles. Namely in the article $12 \S 3$ F.P.C. he predicted that the court taking penalty, penal measure or other measure to a juvenile is directed primarily to educate the perpetrator. In this manner as in the article $54 \$ 1$ P.C. is expressed a particular directive sentencing a juvenile.

\section{The Juvenile Act}

\subsection{Introduction}

The law on juvenile delinquency proceedings creates a model of a paternalistic and welfare approach to juvenile justice, the protection and treatment of the juvenile at risk oriented allowing only a certain range (outside the said article 10 $\$ 2$ of the P.C.), to use criminal sanctions against juvenile perpetrators of prohibited acts ${ }^{26}$. In such a model juvenile it is not treated as an entity with its rights and obligations but as the subject of procedures of the court and the other authorities making decisions for his own good. Committing a prohibited act (a punishable act in principle, which will be discussed later) is only one of the symptoms of the threat. Adopted in the Polish legal system approach to juveniles is in fact the single-track system of dealing with juveniles, which means a uniform approach to both juvenile derogatory criminal law (committing punishable acts), and those who show only signs of demoralization ${ }^{27}$.

25 WILK, Leszek, ZAGRODNIK, Jarosław. Fiscal Penal Code. Commentary. Warsaw: C.H.Beck, 2014, p. 36.

26 According to the Preamble to the J.A., its main objectives are: to counteract the demoralization and delinquency of juveniles, to create conditions for those who have come into conflict with the law or with the rules of acceptable social behaviour, to return to normal life, to strengthen the care and educational functions of the family and its sense of responsibility for the development of children.

27 KONARSKA - WRZOSEK, Violetta. The problem of the need and desirability of changing the principles of responsibility and deeling with minors. Archiwum Kryminologii 20072008, XXIX-XXX, p. 352. 
Fundamentals of action on juvenile cases can occur both independently and also together, and their existence obliges to investigate the case of a juvenile. The doctrine emphasizes that opportunity to start proceedings for a juvenile, not only because of the committed punishable act, but also because of the revealed signs of demoralization expresses the concept of "child in danger", which should come to the aid in connection with the threat of demoralization in the further cultural, civilization and society development. Thus it should be assumed that the J.A. does not introduce any form of liability of juveniles, and these are the base of evidence to initiate proceedings in the case, but not against a juvenile. The point is to take action to apply appropriate measure which will provide support for juvenile ${ }^{28}$.

J.A. is characterized by moving away from the concept of criminal law in the fight against demoralization and the "crime" of juveniles, a parent directive in the whole area of dealing with juveniles is their welfare. It is a basic criterion for the diagnosis of cases of juveniles and its implementation contribute to the general objectives of this law on the prevention and combat against demoralization and the "crime" of juveniles, i.e. depenalization ways to fight the demoralization and the "crime" of juveniles, the flexibility of the procedure, depending on the personality of the juvenile and continuous legal protection ${ }^{29}$.

\subsection{The notion of a Juvenile}

The J.A. departs from the traditional criminal law notion of a juvenile which has already been mentioned, and does not include the typical, uniform definition of a juvenile. Status of a juvenile with the J.A. granted to different age groups of children and young people depending on the situation, with which it is associated. Article $1 \$ 1$ of the J.A. the subjective and objective scope of the J.A. application covers the scope of this Act three categories of juveniles.

The first category includes persons less than 18 years who show symptoms of demoralization and there is a need to prevent and combat demoralization. The minimum age for juveniles displaying signs of demoralization is not provided by the J.A., which is a solution fully legitimate and reasonable. The need to initiate appropriate proceedings in the juvenile case because of demoralization should decide the real purpose of preventing demoralization.

The second category includes juveniles who committed a punishable act after having reached 13 years of age, but before having attained the age of 17 years. The lower limit of 13 years refers to the division of juveniles adopted in the P.C. of 1932 in which the force split into two age groups of juveniles i.e. at the age of 13 as acting without discernment, and from 13 to 17 years as a group of juveniles, for which the statutory presumption assumed that they act with discernment,

28 BOJARSKI, Tadeusz In BOJARSKI, Tadeusz, KRUK, Ewa, SKRĘTOWICZ, Edward. Proceedings in juvenile cases. Commentary. Warsaw: Wolters Kulwer, 2016, p. 55.

29 HAAK, Henryk. Compulsory Treatment of Drug Addicts. Toruń: TNOiK, 2000, p. 65. 
although exceptions were possible. The upper limit circled as 17 years has a close relationship with the principle laid down in the system of criminal law that criminal liability can be held only person at the time of the offence were over 17 years.

The last category of juveniles are persons under the age of 21 years, where the rules of the J.A. apply for the purpose of the implementation of educational or correctional measures which have been adjudged by the court. Juveniles who after having reached the age of 17 years commit a punishable act or after having attained 18 years of age show other signs of demoralization can not be a subject of the regulation despite of the educational or correctional measures are carried out earlier In terms of the performance of educational or correctional measures they will apply the rules of the J.A. to a certain category of "adult offenders" who have committed a prohibited act as an offence, fiscal offence or fiscal petty offence in the age of criminal responsibility (after having attained 17 years of age, but before having attained the age of 18 years), if the criminal court hearing the case considered it appropriate instead of punishment applied to them educational, treatment or correctional measures intended for juveniles (article $10 \$ 4$ of the P.C., article $5 \$ 2$ of the F.P.C., article $73 \$ 1$ in fine of the J.A.). In the literature, as well as in the rulings indicates that the definition of this category of offenders as juveniles is wrong. In fact in terms of young adults who are treated as if they were juveniles in the performance means to them, because in accordance with the Polish criminal law completing 17 years old forever end the period of juvenile ${ }^{30}$.

\subsection{The legal basis for proceedings in juvenile cases}

The law provides two reasons for intervention: the first means that the juvenile shows symptoms of demoralization, the other ones means that the juvenile committed a punishable act. Each of these legal bases has an individual and sufficient character to start intervention.

\subsubsection{The showing signs of demoralization}

According to the article 2 of the J.A. showing signs of demoralization is one of the legal basis for action provided in the J.A. The law does not provide any definition of the notion of "demoralization" but in the article 4 of The J.A. lists by way of example (as indicated by the use of the phrase "in particular") the circumstances indicating it, which include: breaking the principles of community life, committing criminal deed, systemic truancy of compulsory school or vocational training, use of alcohol or other drugs, prostitution, vagrancy and taking part in criminal gangs. Open catalog of circumstances indicating demoralization takes into account some specific external phenomena and behavior resulting from certain disorders determined by the family, school and peer environment. Listed by the legislature symptoms of demoralization are different types of reprehensible

30 MARASZEK, Magdalena. op. cit., p. 77; Ruling of the Supreme Court of 28 November 1989, V KZP 22/89, OSNKW 1990/1-3/6. 
behavior which apart from committing a prohibited act are repetitive behaviors and testify to the demoralization of a juvenile. Some of those in the article $4 \mathbb{\S}$ 1 of the J.A. symptoms of demoralization, such as prostitution, vagrancy, taking part in criminal gangs only because of its repeatability and a high degree of threat to the proper development of the child empower to find that the juvenile is demoralized. Showing signs of demoralization not always evidence of actual demoralization of a person. Such an example may be a prohibited act which the commission can only connect to a lack of care in the management of the interest protected by law or the lack of ability to predict the proper age for a young offender $^{31}$. In such cases the question may arise whether such one-time behavior, although undoubtedly violate the law proves the state or process of demoralization of a juvenile. It is very important to demonstrate that one of the signs of demoralization and committing a punishable act does not constitute ground for the application of educational and correctional measures, if not apparent from the demoralization of the juvenile. Such application comes from a number of specific provisions contained in the J.A., as well as the objectives of the regulations laid down in the preamble to the J.A..$^{32}$.

\subsubsection{The punishable act}

The punishable act constitutes one of the legal basis of the proceedings initiation in juvenile case and must be distinguished from the prohibited act considered on the basis of criminal responsibility. The concept of the punishable act is established in the article $1 \$ 2$ point $2 \mathrm{a}$ and $\mathrm{b}$ of the J.A. According to this regulation a punishable act involves an offence or a fiscal offence and an exhaustively listed types of petty offences that have been identified in twelve indicated articles of the C.P.O. such as: possession in a public place dangerous items; disturbance of peace, public order, or the rest of the night calling the scandal in a public place; destroying, damaging, deleting, making ineffective the sign placed by a state authority to determine the identity of the object, closing it or surrender power regulation; destroying, damaging, removing or making illegible markings or inscriptions warning of imminent danger or fences or other devices to prevent danger; throwing stones or other objects in the motor vehicle in motion; arbitrary setting, destroying, damaging, deleting, enable or disable sign, signal, warning device or security or change their position, obscure or render invisible, and willful destruction, damaging, deleting, or setting tourist mark; driving mechanical or not mechanical vehicle in the state after the use of alcohol or similarly acting substance, as well as not mechanical vehicle in a state of intoxication or under the influence of similarly acting substance; petty theft or misappropriation of someone else's little things, i.e. such, the value of which does not exceed

31 KRUKOWSKI, Adam (ed.). The Juvenile Act. Commentary. Warsaw: Wydawnictwo Prawnicze, 1984, p. 19; GRZEŚKOWIAK, Alicja. Proceedings in Juvenile Cases. Toruń, 1986, pp. 50-51.

32 KONARSKA - WRZOSEK, Violetta. op. cit., p. 62. 
$1 / 4$ of the minimum monthly wage; small fencing intentional and unintentional, if the value of the property does not exceed $1 / 4$ of the minimum monthly wage; the intentional destruction, damage or render unusable someone else's things, the damage does not exceed $1 / 4$ of the minimum monthly wage; speculation entrance fees for artistic events, entertainment or sports; impeding or blocking out of malice or wantonness use of facilities intended for public use, such as in particular: a bench, a device for cleaning, the instrument alarm, lighting, clock, machine, phone, marking the place name, street, park or real estate. Admission to the juvenile other petty offences as well as fiscal petty offences may, however, be considered as a sign of demoralization.

The punishable act prohibited by law in the article $1 \S 1$ point $2 \mathrm{a}$ of the J.A. and therefore act exhaustive offence or fiscal offence, it is also the basis for the decision of the strictest provided in the J.A. measures, i.e. placing in a juvenile correctional centre. According to the article 10 of the J.A. the use of a correction measure in the form of placement in a correctional centre may take place against a juvenile who has committed a punishable act, as referred to in article $1 \$ 1$ point $2 \mathrm{a}$ of the J.A. and for placing him in a correctional centre suggest a high degree of demoralization and the circumstances and nature of the act, especially when other educational measures have proven ineffective or do not augur the resocialization of the juvenile. Both of these conditions must occur together. The use of a correctional measure was therefore limited to a juvenile offender who has committed a punishable act corresponding to the notion of offence, not in case of a petty offence. This narrowing of the applicability of placement in a correctional centre is right as a rule but it may be unreasonable in relation to a specific case where a juvenile perpetrator of several petty offences will show a higher degree of demoralization than the offender of a criminal offence ${ }^{33}$.

\subsection{Measures imposed in Juvenile Cases}

Consequence of the finding symptoms of demoralization or committing the punishable act by a juvenile is the possibility of a judgment by a court of educational, therapeutic, corrective measures, and exceptionally - the penalty.

\subsubsection{The educational, educational - therapeutic measures and the corrective measure}

The measures provided for in the J.A. shall be applied by the principle of expediency and is subordinated to the juvenile's interest. A characteristic feature is that they have an indeterminate character, i.e. they are imposed in principle for an indefinite period time, as is the case of penalty. These measures are used as long as it is needed to achieve the educational effects, but not longer than until

33 Rulings of the Supreme Court of 9 October 2002, III KKN 563/00, Legalis; of 29 October 2002, III KKN 353/02, Legalis; of 22 April 2009, III KK 21/09, Legalis. 
the age of 18, and for the purpose of the implementation of juvenile measures which have been adjudged by the court but not longer than till the age of $21^{34}$.

The court is not obliged to apply these measures and has complete freedom in their selection. This does not regard only the corrective measure of placing a juvenile in correctional center for which the legislature clearly circled the statutory rule (article 10 of the J.A.). A catalog of possible measures that may be imposed has been included in the article 6 of the J.A. It includes: caution; obligation to behave in a certain way, especially to repair the damage, to do unpaid work for the benefit of the victim or local community, to offer an apology to the victim, to start education at school or employment, to take part in educational or therapeutic trainings, to refrain from presence in certain milieus or places, to refrain from use of alcohol or drugs; responsible supervision by parents or by custodian; supervision by a youth organization or other association, an employer or trusted person, who is obliged to guarantee for juvenile's proper conduct; supervision by a probation officer; directing the juvenile to a probation center, a social organization or institution providing care, therapy or training for juveniles, applied with the consent of these institutions or organizations; withdrawal of driver's license; forfeiture of the proceeds of the punishable act; ordering the juvenile to be put in a foster family, in an appropriate child or educational institution, or in training and educational center; correctional center; other measures under the J.A. or Family Code.

The measures referred to as educational include the measures listed in the article 6 points $1-9$ of the J.A. Educational - therapeutic measures are listed in the article 12 of the J.A. They may be applied to juveniles suffering from mental deficiency, mental disease, some kind of mental disorder or from alcohol and drug addiction. These measures consist in placing juveniles in a psychiatric hospital or other suitable health institution. If there is a need to ensure only care and protection, the juvenile may be placed in a social welfare institution or in suitable educational center. A corrective measure, as already indicated, there is only one, and has the form of placing a juvenile in a correctional center (article 6 point 10 of the J.A.), wherein this arrangement may rely both on the actual placement of juveniles in the correctional center, as well as, can be conditionally suspended.

\subsubsection{The penalty}

The legislator reserves in the art. 5 of the J.A. that in the cases provided for by law, if other measures are not able to provide rehabilitation of a juvenile penalty may be imposed. On the basis of the J. A. the legal basis for the imposition of a juvenile penalty is provided for in the article 94 of the J.A. This regulation provides for the imposition of a juvenile penalty in a situation in which a juvenile adjudicated placement in the correctional center but the measure has not been

34 KOBES, Pawel. Adjudication and execution of a sentence of imprisonment of juveniles in Poland. Warsaw: Difin, 2015, p. 69. 
implemented to execute and a juvenile has already completed 18 years. The provision does not specify when the reasons which made it not been for placing a juvenile in a correctional center, and therefore it is assumed that they can be both the cause dependent juvenile (e.g. hiding), as well as beyond its control (e.g. a conditional suspension of the placement, the postponement of inclusion, health prevents placement of the plant, etc.). The court decides whether a measure ordered to perform or withdraw from its implementation and impose a juvenile penalty of compulsory extraordinary easing her, especially when a juvenile will achieve 21 years of age soon. The legislator states that in the event of the imposition of a penalty of imprisonment or a penalty of restriction of liberty its duration may not exceed the period remaining for the completion of the offender 21 years.

Article 94 of the J.A. also provides self-contained independent from the ground indicated in the P.C to withdraw from the punishment, especially when maintaining the perpetrator was a significant improvement, which is shown in progress in the educational work with juvenile.

The principle that the futility of accession to the enforcement of the decision on the placement of a juvenile offender in a correctional facility after he attains the age of 18 may justify the passage of punishment has had some arguments. At the same time there are doubts concerning the principle of guilt. The imposition of a juvenile penalty follows an earlier decision to place a juvenile in a reformatory, which did not happen for various reasons. Joining the enforcement of the judgment occurs when a juvenile is already 18 years old. It comes to change the decision to replace the reformatory punishment that can be imposed for the offence. Punishment should instead be coupled with the guilt which was not yet determined when decision of placing the juvenile in a correctional center was determined. Determining the amount of the penalty meted out in place of the predicate pre-correction measure implies the need to re merits of the case, including the need to establish the guilt of a juvenile which as rightly pointed doctrine prevents the use of the standard in an automatic manner by simple conversion put in a correctional centre for penalty ${ }^{35}$.

Reassessment of a past event, once already assessed in the context of punishment for juveniles under article 94 of the J.A. may raise some doubts. According to T. Bojarski can not be a practical solution that question. Since the P.C. in article $10 \$ 2$ allows to reduce the lower limit of criminal responsibility to 15 years of age, the action provided for in article 94 of the J.A. is also fully justified. Responsibility pursuant to article $10 \$ 2$ P.C. also can not ignore the issue of guilt, as has already been mentioned. In the case of article 94 of the J.A. important indication in this regard may be included in the opinion deliberative team of court experts, who usually speaks in terms of the so-called discernment of a juvenile (although the rules of the J.A. do not use this term). The replacement of correctional centre

35 BOJARSKI, Tadeusz. op. cit., p. 235. 
on penalty under article 94 of the J.A. should not apply (the same way as it does under article $10 \$ 2$ P. C.) for minors under 15 years of age and is only possible before the end of the juvenile 21 years $^{36}$.

With respect to article 94 of the J.A. withdrawal from the punishment it should be noted that the fact that a juvenile is not started to execute a correction measure by reaching his 18 years, can not be a spontaneous basis to waive the punishment. The legislator expressly reserves fact that exemption from punishment may be "in particularly justified cases, especially when the behavior of the perpetrator was a significant improvement". This means that the decision by the court important criterion is to change the behavior of a juvenile which may include among others on undertaking study or work, fulfillment of the obligations imposed or permanent break contact with undesirable environment. Improving behavior although undefined by the legislature as a long-term it should be sufficiently justified specific facts that it could inspire confidence about its durability ${ }^{37}$. Against automatically abandon of punishment can also speak that the placement of the correctional centre decides a high degree of demoralization of the juvenile, the circumstances and the nature of a punishable act and the ineffectiveness or absence of a favorable prognosis of rehabilitation in the use of educational measures. Arguments in favor of placing the juvenile in a correctional centre or the imposition of a penalty must be balanced in a particularly insightful.

Depending on the threat of sanctions for the perpetrators of an act attributable to a court, except imprisonment, the possibility of imposing penalties for non-custodial penalties in the form of restriction of liberty or a fine, not excluding the possibility of imposing punitive measures. And although the formal imposition of a juvenile penalty under the article 94 of the J.A. does not mean a conviction, which also emphasizes the Supreme Court, a ruling the court must sentence the offender to assign blame in line with the principle of nulla poena sine culpa $a^{38}$.

36 BOJARSKI, Tadeusz. op. cit., p. 274.

37 GROMEK, Krystyna. Commentary to the Juvenile Act. Warsaw: LexisNexis, 2004, p. 403.

38 Ruling of the Supreme Court of 24 April 1985, VI KZP 1/85, OSNKW 1985/7-8/52. 